\title{
First Case of Foot Drop Associated with Capecitabine in a Patient with Thymidylate Synthase Polymorphism
}

\author{
Andrew B. Wilks ${ }^{1}$, Muhammad W. Saif ${ }^{2}$ \\ 1. Tufts Medical Center, Tufts University School of Medicine 2. Hematology/Oncology, Tufts Medical \\ Center
}

$\square$ Corresponding author: Muhammad W. Saif, wsaif@tuftsmedicalcenter.org

Disclosures can be found in Additional Information at the end of the article

\section{Abstract}

Capecitabine, an oral prodrug of 5-FU, has been approved by the FDA for use in patients with breast and colon cancers. In addition, capecitabine is commonly used in patients with other malignancies such as pancreatic, gastroesophageal, and hepatobiliary tract cancers. Though cerebellar toxicity is a rare but well-known side effect of intravenous 5-FU therapy, peripheral neuropathy with capecitabine has only been described in rare cases. In this case report, we describe a 79-year-old patient with locally advanced adenocarcinoma of the pancreas undergoing chemoradiation therapy with capecitabine who developed peripheral sensorimotor neuropathy. To the best of our knowledge, this is the first patient in the literature who was found to have two mutations (2R) of a 28 base-pair tandem repeat in the $5^{\prime}$ promoter enhancer region (5'-TSER) on both alleles (2R/2R) of thymidylate synthetase (TYMS) gene, possibly responsible for the neurotoxicity.

Categories: Neurology, Oncology, Genetics

Keywords: capecitabine, 5-fluorouracil, dihydropyrimidine dehydrogenase (dpd), peripheral neuropathy, foot drop, thymidylate synthase (ts), pharmacogenetics

Received 12/22/2016 Review began 01/03/2017 Review ended 01/19/2017 Published 01/24/2017

\section{C) Copyright 2017}

Wilks et al. This is an open access article distributed under the terms of the Creative Commons Attribution License CC-BY 3.0., which permits unrestricted use, distribution, and reproduction in any medium, provided the original author and source are credited.

\section{Introduction}

Capecitabine is a rationally designed oral formulation of fluoropyrimidine that is absorbed intact through the intestinal wall and then converted to 5-FU in three sequential enzymatic reactions, the third step being mediated by the enzyme thymidine phosphorylase (TP) at tissue level [1]. TP is known to be present in significantly higher concentrations in cancer cells than in plasma or surrounding normal tissue, thus producing a higher intratumoral concentration of 5FU, thereby inducing a better anti-tumor effect while simultaneously sparing many of the systemic toxicities associated with 5-FU. Radiation has shown to upregulate TP, producing more 5-FU within the tumor tissue [2]. Pancreatic xenograft studies from our laboratory demonstrated a synergistic anti-tumor effect with concomitant capecitabine and radiotherapy in both radiated and contralateral lead-shielded tumors in the same animals (abscopal effects) [3]. We pioneered a phase I study, which concluded that capecitabine $800 \mathrm{mg} / \mathrm{m} 2$ BID with concurrent radiation therapy is feasible in patients with locally advanced pancreatic cancer (LAPC) [4]. Compared to intravenous 5-FU, capecitabine is associated with a lower incidence and severity of diarrhea, stomatitis, nausea, and neutropenia, but with an increased rate of hand-foot syndrome. This approach offers an easy alternative to intravenous fluorouracil as a radiosensitizer. This hypothesis was further confirmed in a phase II study by our group [5] and then all the major cooperative groups adopted capecitabine as a radiosensitizer of choice in this setting. 


\section{Cureus}

Peripheral neuropathy has been reported with 5-FU given alone as well as when in combination with chemotherapy agents that are known to produce cumulative peripheral neuropathy such as platinum analogs and taxanes [6]. To our knowledge, there has been only one prior report describing two patients who developed a delayed onset peripheral neuropathy following administration of capecitabine, as our group published the first two cases that developed peripheral neuropathy secondary to capecitabine (Table 1) [7]. However, in this paper, we describe the first case of foot drop associated with capecitabine in a patient with thymidylate synthase (TYMS) polymorphism. Informed consent was obtained from the patient for this study. 


\section{Cureus}

\begin{tabular}{|c|c|c|c|c|c|c|}
\hline Reference & Age/gender & $\begin{array}{l}\text { 5- } \\
\text { FU/Xeloda } \\
(\mathrm{mg} / \mathrm{m} 2)\end{array}$ & $\begin{array}{l}\text { Concurrent } \\
\text { chemotherapy/radiation }\end{array}$ & Neurotoxicity & Treatment & Outcome \\
\hline $\begin{array}{l}\text { Stein, et } \\
\text { al. } 1998\end{array}$ & 71 male & $\begin{array}{l}450 \text { i.v. push } \\
\text { daily } \times 5\end{array}$ & Levamisole & $\begin{array}{l}\text { Pain in lower } \\
\text { limbs }\end{array}$ & $\begin{array}{l}\text { RTX } \\
\text { discontinued }\end{array}$ & $\begin{array}{l}\text { Discontinued Symptoms } \\
\text { stabilized until the patient } \\
\text { was rechallenged with 5- } \\
\text { FU and leucovorin for } \\
\text { liver metastasis; } \\
\text { subsequent deterioration } \\
\text { in neurotoxicity occurred } \\
\text { requiring discontinuation } \\
\text { of 5-FU/LV }\end{array}$ \\
\hline $\begin{array}{l}\text { Stein, et } \\
\text { al. } 1998\end{array}$ & 54 female & $\begin{array}{l}450 \text { i.v. push } \\
\text { daily } \times 5\end{array}$ & Levimasole & $\begin{array}{l}\text { Pain and } \\
\text { numbness in } \\
\text { lower limbs }\end{array}$ & $\begin{array}{l}\text { RTX } \\
\text { discontinued }\end{array}$ & $\begin{array}{l}\text { Improved but incomplete } \\
\text { resolution }\end{array}$ \\
\hline $\begin{array}{l}\text { Saif, et al. } \\
2001\end{array}$ & 65 male & $\begin{array}{l}65 \text { p.o. days } \\
\text { one -three } \\
\text { weekly } x \\
\text { three of four } \\
\text { weeks }\end{array}$ & Leucovorin + Eniluracil & $\begin{array}{l}\text { Reduced } \\
\text { sensation in } \\
\text { leg leading to } \\
\text { unsteady gait }\end{array}$ & $\begin{array}{l}5-\mathrm{FU} \text { dose } \\
\text { reduced }\end{array}$ & $\begin{array}{l}\text { Symptoms stabilized with } \\
\text { dose reduction; gradually } \\
\text { improved after RTX } \\
\text { stopped with persistent } \\
\text { foot drop }\end{array}$ \\
\hline $\begin{array}{l}\text { Saif, et al. } \\
2001\end{array}$ & 70 male & $\begin{array}{l}23.4 \text { p.o. } \\
\text { days one- } \\
\text { three } \\
\text { weekly } x \\
\text { three of four } \\
\text { weeks }\end{array}$ & Leucovorin + Eniluracil & $\begin{array}{l}\text { Reduced } \\
\text { sensation in } \\
\text { leg leading to } \\
\text { unsteady gait }\end{array}$ & $\begin{array}{l}5-\mathrm{FU} \text { dose } \\
\text { reduced }\end{array}$ & $\begin{array}{l}\text { Symptoms stabilized with } \\
\text { dose reduction; gradual } \\
\text { but incomplete }\end{array}$ \\
\hline $\begin{array}{l}\text { Saif, et al. } \\
2004\end{array}$ & 50 female & $\begin{array}{l}2500 \mathrm{mg} / \mathrm{m} 2 \\
\text { in two } \\
\text { divided } \\
\text { doses x } 14 \\
\text { days q21 } \\
\text { days }\end{array}$ & None & $\begin{array}{l}\text { Perioral and } \\
\text { bilateral } \\
\text { tingling, } \\
\text { numbness in } \\
\text { hands }\end{array}$ & $\begin{array}{l}\text { CAP dose } \\
\text { reduced }\end{array}$ & Symptoms resolved \\
\hline $\begin{array}{l}\text { Current } \\
\text { case and } \\
\text { Saif, et al. } \\
2004\end{array}$ & 65 male & $\begin{array}{l}1600 \mathrm{mg} / \mathrm{m} 2 \\
\text { in two } \\
\text { divided } \\
\text { doses } x \text { six } \\
\text { weeks }\end{array}$ & Radiation (5.4 cGy) & Foot drop & $\begin{array}{l}\text { CAP held; } \\
\text { later } \\
\text { reduced }\end{array}$ & $\begin{array}{l}\text { Improved but incomplete } \\
\text { resolution }\end{array}$ \\
\hline
\end{tabular}

\section{TABLE 1: Summary of patients who developed peripheral neuropathy following administration of 5-FU/Xeloda-based chemotherapy}

\section{Case Presentation}

The patient was a 79-year-old Caucasian male with locally advanced adenocarcinoma of the 
pancreas encasing the superior mesenteric artery and celiac ganglion. His past medical history includes a hiatal hernia, varicosities in the legs, and mild hypertension. Current medications include pancrelipase, omeprazole, and lisinopril. He smoked about one pack of cigarettes per day for 40 years but stopped at the age of 55 years and denied alcohol abuse. At the initial oncologic evaluation, his physical examination did not reveal any abnormality except varicose veins on the left leg more than right. Neurological examination was also normal. He was able to ambulate without any assistance and was able to do all activities of daily living (ADLs).

The patient started chemoradiation therapy consisting of capecitabine $(1600 \mathrm{mg} / \mathrm{m} 2$ in two divided doses $=3200 \mathrm{mg} / \mathrm{m} 2$ per day Monday to Friday with weekends off), with concurrent radiation (50.4 Gy in 28 fractions over 5.5 weeks). He tolerated the combination therapy extremely well for the first three weeks without any major toxicity except grade one nausea, grade one vomiting, grade one diarrhea and grade one hand-foot syndrome. On day three of the 4th week, he presented to the oncology clinic with new onset of gait abnormality noticed by his son that morning. The son noticed that the patient was dragging the front of his right foot on the ground when he walked. The patient further confirmed that he developed a new difficulty lifting the front part of his foot that morning when he wanted to walk to the restroom. No gross abnormal findings were elucidated on neurological examination, including cranial nerves, except unsteady gait with right-sided foot-dragging, impaired heel-toe walking, diminished sensation to pinprick in the lower extremities, and decreased distal motor strength. A magnetic resonance imaging scan of the brain and thoracolumbar spines was unremarkable. Laboratory studies including complete blood count, chemistry, liver function tests, vitamin B12, thyroid stimulating hormone (TSH) test, rheumatoid factor, thiamine levels, antibodies against doublestranded DNA phospholipid and cardiolipin were collected and all came within normal limits. The patient was not receiving any other potentially neurotoxic medications. Nerve conduction studies and electromyogram revealed acute, axonal sensorimotor polyneuropathy with secondary demyelinative features, with an increasing proximal to distal neuropathic gradient (Figure 1).

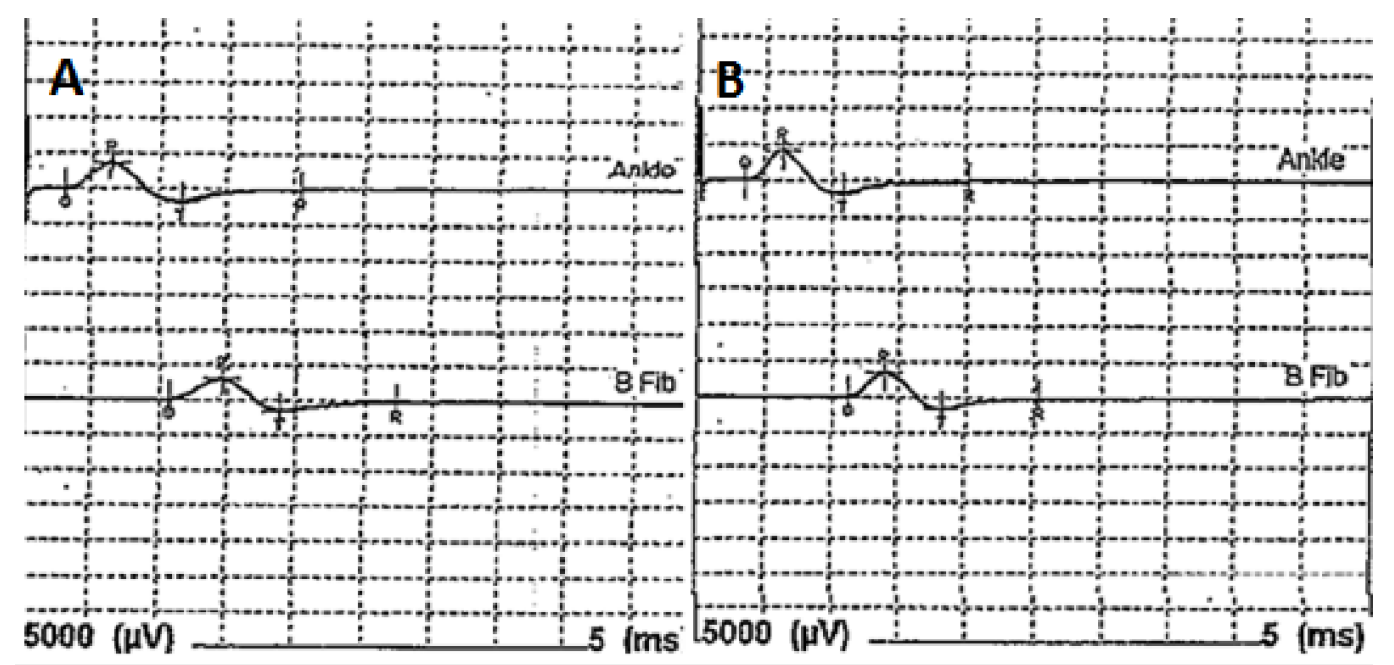

FIGURE 1: Initial EMG of bilateral peritoneal motor nerves shows peripheral nerve damage to right in comparison to left

EMG of right peritoneal motor nerve (A) shows increased latency, increased duration, decreased amplitude and decreased complexity of the motor unit action potentials (MUAP) in comparison to left peritoneal motor nerve (B), indicating denervation secondary to capecitabine chemotherapy 
We immediately halted administration of capecitabine, consulted neurology as well as physical therapy. Neurology agreed with our assessment and suggested not to resume the drug as no other etiology was found. They suggested to rule out cancer progression as sometimes these neurological abnormalities might be manifesting paraneoplastic syndrome and the repeat CT imaging of scan of the abdomen, pelvis, and chest showed a slight improvement in tumor size in the pancreas and no distant metastasis.

In addition to above tests, we also performed genetic studies related to capecitabine including dihydropyrimidine dehydrogenase (DPD) deficiency and thymidylate synthase (TYMS) polymorphism. DPD gene mutation analysis (Quest Diagnostics Nichols Institute-San Juan Capistrano, CA) was negative for the IVS14+1G>A mutation in the DPD gene, which accounts for $50 \%$ of the DPD deficiency alleles. However, the patient was found to have two mutations (2R) of a 28 base-pair tandem repeat in the 5' promoter enhancer region (5'-TSER) on both alleles $(2 \mathrm{R} / 2 \mathrm{R})$ of TYMS gene. This $2 \mathrm{R} / 2 \mathrm{R}$ genotype predicts low TYMS expression.

The patient's symptoms slightly improved within the next four weeks after holding capecitabine and initiation of physical therapy. However, after one week of delay, he finished the remaining fractions of radiation therapy, impressed by the CT scan findings showing shrinkage of the tumor. After a short break of two weeks, he came back to the oncology clinic for further discussion on treatment. After extensive discussion, the decision was made to proceed with a different chemotherapy and hence single agent gemcitabine $1000 \mathrm{mg} / \mathrm{m} 2 \mathrm{weekly}$ $\mathrm{x}$ three out of four weeks was administered starting after another two weeks delay. At that time, he had gradual improvement in his gait (using a cane), balance and coordination. He received a total of six cycles (four weeks = one cycle) of gemcitabine with no new neurological deficit.

Physical examination of seven months after discontinuing revealed residual grade two sensory loss in the feet and grade one motor loss with dorsiflexion. Repeat electromyogram (EMG) test at that time (Figure 2) showed chronic peripheral nerve degeneration, despite the improvement of symptoms.
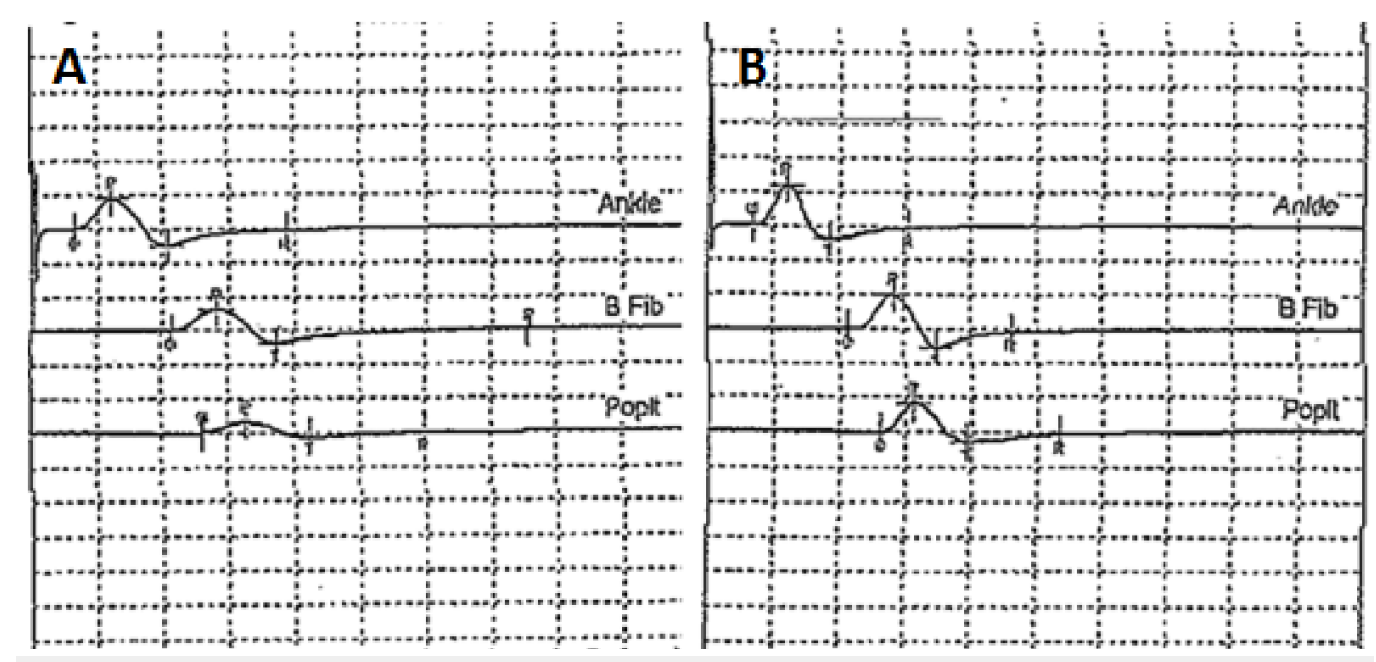

FIGURE 2: EMG of peritoneal motor nerves at seven months shows ongoing peripheral nerve damage to right in comparison to left

EMG of right peritoneal nerve (A) shows decreased amplitude and decreased complexity of MUAP in comparison to left peritoneal motor nerve (B), indicating ongoing peripheral nerve damage months after cessation of capecitabine chemotherapy 


\section{Discussion}

The 5-fluorouracil (5-FU) and its prodrug capecitabine are the third most commonly used agents in oncology for the treatment of various cancers. The majority of the randomized phase III studies have shown comparable end results when comparing capecitabine and 5-FU; though capecitabine offers the advantages of oral convenience and less bone marrow suppression. The most common side effects of capecitabine include diarrhea, neutropenia, and alopecia although capecitabine (CAP) causes more cases of severe hand-foot syndrome. Capecitabine is metabolized to 5 -FU via a three-step enzymatic process, the last step catalyzed by TP $[1,5]$. In addition, TP is also involved in the activation of 5-FU into fluorodeoxyuridine that will further inhibit the DNA synthesis. Tumor concentration of TP is three-10 times higher than the healthy tissue. This can enable selective drug activation of 5-FU at the tumor site and possibly decrease systemic toxicity [8].

In addition to TP, other genes, such as TYMS, are considered as potential factors for 5-FU toxicity and efficacy. TYMS is strongly inhibited by $5-\mathrm{FU}$ and considered to be the major drug target. TYMS catalyzes the intracellular conversion of deoxyuridylate to deoxythymidylate that is the sole de novo source of thymidylate, an essential precursor for DNA synthesis. The active metabolite of 5-FU, 5-fluorodeoxyuridylate (5FdUMP), binds to TYMS and inhibits it by forming a stable tertiary complex. The human TYMS is polymorphic with either double or triple tandem, repeats of a 28 base-pair sequence downstream of the cap-site in the 59-terminal regulatory region. The TYMS genotype predicts TYMS mRNA expression in metastasized colon tumors and normal liver tissue as well as predicts response and toxicity to 5-FU [9].

Finally, 5-FU is catabolized into dihydrofluorouracil by the DPD enzyme that is present in almost all tissues. DPD is the initial rate-limiting enzyme in the catabolism of 5-FU. Polymorphic abnormality of DPYD gene is one of the most well known pharmacogenetic syndromes in medical oncology at present [8]. Patients with DPD deficiency experience profound systemic toxicity following the administration of 5-FU or capecitabine presumably secondary to prolonged exposure to 5-FU due to decreased drug catabolism.

Capecitabine, an oral prodrug of 5-FU, has been found in higher concentrations in cancer cells when administered concurrently with radiation therapy. This is due to a higher concentration of TP, the final of three proteins, which convert capecitabine to 5-FU, in cells damaged by radiation $[1,4]$. One can argue that uncommon toxicities may occur due to this synergy as we have previously published [10]. Our patient was found to have two mutations (2R) of a 28 basepair tandem repeat in the 5' promoter enhancer region (5'-TSER) on both alleles (2R/2R) of TYMS gene. This $2 \mathrm{R} / 2 \mathrm{R}$ genotype predicts low TYMS expression. While controversy exists in the literature, overall this finding predicts improved survival of patients with colorectal adenocarcinoma receiving 5-FU chemotherapy but also increased the risk for 5-FU toxicity. Our patient was found to have no abnormalities of DPD. This report is the first in medical literature associating peripheral neuropathy to TYMS abnormality in a patient receiving capecitabine. It has been published prior that capecitabine crosses the blood-brain barrier, though the biochemical basis of neurological toxicities has not been elucidated.

Neurological side effects have been reported on rare occasions and should be borne in mind while administrating this class of drugs to patients. Dose adjustment and discontinuation must be assessed in any patient developing side effects to 5-FU therapies.

\section{Conclusions}

In this case report, we describe a 79-year-old patient with locally advanced adenocarcinoma of the pancreas, undergoing chemoradiation therapy with capecitabine who developed peripheral sensorimotor neuropathy. Peripheral sensory motor conduction studies confirmed peripheral 
neuropathy. Pharmacogenetic studies related to genes associated with 5-FU metabolism showed polymorphism of TS, possibly causing the nerve damage in this patient. Regardless, dose reduction or discontinuation of capecitabine therapy is indicated in any patient who develops these complications.

\section{Additional Information \\ Disclosures}

Human subjects: Consent was obtained by all participants in this study. Conflicts of interest: In compliance with the ICMJE uniform disclosure form, all authors declare the following: Payment/services info: All authors have declared that no financial support was received from any organization for the submitted work. Financial relationships: All authors have declared that they have no financial relationships at present or within the previous three years with any organizations that might have an interest in the submitted work. Other relationships: All authors have declared that there are no other relationships or activities that could appear to have influenced the submitted work.

\section{References}

1. Saif MW: Targeting cancers in the gastrointestinal tract: role of capecitabine . Onco Targets Ther. 2009, 2:29-41.

2. Saif MW, Joseph M, Tang S, Vickers S, Plants B, Russo S: Retrospective analysis of capecitabine and radiation therapy in the treatment of pancreatic cancer. J Appl Res. 2004, 4(4):635-646.

3. Blanquicett C, Saif MW, Buchsbaum DJ, Eloubeidi M, Vickers SM, Chhieng DC, Carpenter MD, Sellers JC, Russo S, Diasio RB, Johnson MR: Antitumor efficacy of capecitabine and celecoxib in irradiated and lead-shielded, contralateral human BxPC-3 pancreatic cancer xenografts: clinical implications of abscopal effects. Clin Cancer Res. 2005, 11 (24):8773-81. 10.1158/1078-0432

4. Saif MW, Eloubeidi MA, Russo S, Steg A, Thornton J, Fiveash J, Carpenter M, Blanquicett C, Diasio RB and Johnson MR: Phase I study of capecitabine with concomitant radiotherapy for patients with locally advanced pancreatic cancer: expression analysis of genes related to outcome. J Clin Oncol. 2005, 23 (34):8679-8687.

5. Saif MW, Black G, Roy S, Bell D, Russo S, Eloubeidi MA, Steg A, Johnson MR, Zelterman D and Diasia RB: Phase II study of capecitabine with concomitant radiotherapy for patients with locally advanced pancreatic cancer: up-regulation of thymidine phosphorylase. Cancer J. 2007, 13(4):247-56.

6. Saif MW, Wilson RH, Harold N, Keith B, Dougherty DS, Grem JL: Peripheral neuropathy associated with weekly oral 5-fluorouracil, leucovorin and eniluracil. Anticancer Drugs. 2001, 12(6):525-31.

7. Saif MW, Wood TE, McGee PJ, Diasio RB: Peripheral neuropathy associated with capecitabine . Anticancer Drugs. 2004, 15:767-771.

8. Saif MW, Juneja V, Black G, Thronton J, Johnson MR, Diasio RB: Palmar-plantar erythrodysesthesia in patients receiving capecitabine and intratumor thymidine phosphorylase and dihydropyrimidine dehydrogenase: is there a pharmacologic explanation?. Support Cancer Ther. 2007, 4(4):211-218. 10.3816/SCT.2007.n.017

9. Shahrokni AI, Rajebi MR, Saif MW: Toxicity and efficacy of 5-fluorouracil and capecitabine in a patient with TYMS gene polymorphism: A challenge or a dilemma?. Clin Colorectal Cancer. 2009, 8(4):231-4. 10.3816/CCC.2009.n.039

10. Saif MW, Black G, Johnson M, Russo S, Diasio R: Radiation recall phenomenon secondary to capecitabine: possible role of thymidine phosphorylase. Cancer Chemother Pharmacol. 2006, 58(6):771-775. 10.1007/s00280-006-0223-8 